100. Manifestar dos sem manifestos, dos duzentos manifestos, dos 300 milhões, vezes 8 mais $3 .^{1}$

8. Esse manifesto funciona (?) por maquiniologias: inutilizadas, precarizadas, ferrugem e esterco.

3. Dilacerar o eu-ego e o funcionalismo essencial do ser histórico.

1. Pauta da greve: o inútil será inutilizado.

1848. Nós manifestamos diariamente a autonomia do trabalho inútil, por isso a greve do inútil é o manifesto.

69. Não pararemos o Brasil, trabalhadores da causa com codinome estabelecido de entretenimento, somos em paragem o movimento manifestado.

7. 0 manifesto não precisa de uma linguagem própria, por isso a partir de hoje não faremos mais manifestos.

${ }^{1} 300000000 \times 8+3=$ Vocês ainda continuam falando do mesmo jeito, e da mesma forma as mesmas coisas, o manifesto ainda é assim de 600 anos manifestados. As coisas de sempre se dilaceraram, exposta podridão constitucional -nós também falamos igual, nós estamos desejantes de greve mesmo, manifesto.

\section{Mari Brites}

2016. Somos em manifesto.

500. Não arrancamos as casquinhas de nossas feridas ancestrais.

64. Nossa greve é por uma cicatriz histórica: sangrada, roubada e torturada.

0. Não temos dinheiro. Nem estamos à venda.

13. Não sorrimos à toa, nem choramos por causas nobres.

11. Em resistência à sabotagem daquilo que nunca se quis, quando o insuportável daquilo que fomos manifesta mudança muda.

//. Não é uma greve do ócio, é a greve do inútil!

\$\$. Arte é inútil.

A.C. Inutilizar manifestos, gestos, ações, relações intrínsecas, indizíveis, incorporais que, corporificadas, ostentem sua relação com a própria inutilidade. 
XXY. Separar, banir, decantar, renomear qualquer ato que possa ser mantido pela obviedade de sua falta e/ou excesso de utilidade.

54.000.000 Greve manifestada: a arte de ser inútil e a diferença do inútil enquanto arte.

\&. Secar a última gota de inutilidade que nossos corpos possam oferecer.

Evocar: paralisia, estagnação, imobilidade.

24. Estagnar ao sol sob a bandeira da exaustão multicolor, empalamo-nos.

17/04. Exaustão estagnada escancarada: encarar-se. $(! ! !)$
22. Inutilitarismo: paralisação arquitetada em greve que valor não convém.

23. Treino habitual para inutilidade de greve: paralisia evocada enquanto paradoxo. Corpo parado em potência de aparição, corpo em paragem grávida de ação.

n+1. Corpo estático em vibração eterna - microscópica.

n-1. R e d u z i $r$ o t e m p o p a $r$ a e n c o n t r a $r$ o corpo de antes/outro.

\%. Estagnação para encontro do tempo das outras coisas, corpo mineral, animal, vegetal, ancestral.

000. Inutilidade $=$ você $=\mathrm{eu}=300000000 \times 8+3$ (animal) = sem manifestos, duzentos manifestos.... . 